\title{
Diversity and distribution of aquatic insects in Southern Brazil wetlands: implications for biodiversity conservation in a Neotropical region
}

\author{
Leonardo Maltchik*, Marina Schmidt Dalzochio, Cristina Stenert \& Ana Silvia Rolon \\ Laboratory of Ecology and Conservation of Aquatic Ecosystems, Av. Unisinos, 950 CEP 93.022-000, UNISINOS, \\ São Leopoldo, RS, Brazil; UNISINOS, São Leopoldo, Brazil; maltchik@unisinos.br, mahsdalzochio@gmail.com, \\ cstenert@unisinos.br, asrolon@gmail.com \\ * Corresponding author
}

Received 22-III-2011. C Corrected 30-VI-2011. Accepted 28-VII-2011.

\begin{abstract}
The selection of priority areas is an enormous challenge for biodiversity conservation. Some biogeographic methods have been used to identify the priority areas to conservation, and panbiogeography is one of them. This study aimed at the utilization of panbiogeographic tools, to identify the distribution patterns of aquatic insect genera, in wetland systems of an extensive area in the Neotropical region $\left(280000 \mathrm{~km}^{2}\right)$, and to compare the distribution of the biogeographic units identified by the aquatic insects, with the conservation units of Southern Brazil. We analyzed the distribution pattern of 82 genera distributed in four orders of aquatic insects (Diptera, Odonata, Ephemeroptera and Trichoptera) in Southern Brazil wetlands. Therefore, 32 biogeographic nodes corresponded to the priority areas for conservation of the aquatic insect diversity. Among this total, 13 were located in the Atlantic Rainforest, 16 in the Pampa and three amongst both biomes. The distribution of nodes showed that only $15 \%$ of the dispersion centers of insects were inserted in conservation units. The four priority areas pointed by node cluster criterion must be considered in further inclusions of areas for biodiversity conservation in Southern Brazil wetlands, since such areas present species from different ancestral biota. The inclusion of such areas into the conservation units would be a strong way to conserve the aquatic biodiversity in this region. Rev. Biol. Trop. 60 (1): 273-289. Epub 2012 March 01.
\end{abstract}

Key words: panbiogeography, track analysis, priorities areas, biome, aquatic invertebrates.

The selection of priority areas is a huge challenge for biodiversity conservation (Sarkar \& Margules 2002). Systematic methods for identifying biodiversity priority areas require good data on the distribution and abundance patterns of the species richness, diversity and composition (Margules et al. 2002). Some phylogenetic and biogeographic methods are used for identifying the priority areas for conservation.

Among the biogeographic methods, the panbiogeography identifies, through the recognition of generalized and biogeographic tracks, the centers of origin and the biota evolution patterns and distribution of the species (Craw et al. 1999). The areas selected by panbiogeographic criteria are interesting for the conservation (Morrone 1999) as they represent the true biodiversity hotspots (Crisci et al. 2003).

Biogeographic data for prioritizing the selection of areas for conservation has been used in several countries of South America (Morrone \& Lopretto 1994, Menu-Marque et al. 2000, Contreras-Medina \& Eliosa-León 2001, Franco-Rosselli 2001, Morrone 2001, Morrone 2003, Roig-Juñent et al. 2003), including Brazil (Franco-Rosselli \& Berg 1997, Carvalho et al. 2003, Lowenberg-Neto \& Carvalho 2004, Morrone 2004, Morrone et al. 2004, Prevedello \& Carvalho 2006). These works were carried out for different group of organisms such as coleopterans in the Andes (Morrone 
1999), plants and birds in Mexico (Luna-Vega et al. 2000, Mondragón \& Morrone 2004), and gymnosperms in the world (Contreras-Medina et al. 1999, 2001a,b) being carried mainly in terrestrial ecosystems.

In wetlands, panbiogeographic methods have been little used for selecting the areas for biodiversity conservation. In such ecosystems, other models, e.g. the species-area relationship, have been used more in wetland conservation planning and management (Gibbs 2000), including Brazil (Guadagnin \& Maltchik 2007, Stenert et al. 2007, 2008, Rolon et al. 2008). The hydroperiod and habitat heterogeneity also have been used as criteria for conservation of wetland communities (Collinson et al. 1995, Snodgrass et al. 2000, Babbitt 2005, Van Geest et al. 2005).

The search for ecologic criteria for the selection of priority wetlands is important, since these ecosystems are amongst the most affected and degraded ecological systems. Almost half of the wetlands in the world disappeared in the last century (Shine \& Klemm 1999). In Southern Brazil, conservative data indicate that $90 \%$ of the wetlands have disappeared. Maltchik (2003) consider that approximately $72 \%$ of the remaining wetlands are smaller than $1 \mathrm{~km}^{2}$. This pattern is a consequence of a severe habitat fragmentation due to agricultural expansion, especially rice plantations (Gomes \& Magalhães 2004). Such information is extremely worrisome, since less than $2 \%$ of the surface land in Southern Brazil is protected by conservation areas (MMA 2006).

Southern Brazil is in an extensive area of Neotropical region $\left(\sim 280000 \mathrm{~km}^{2}\right)$, represented by two large biomes of high biodiversity, endemism, and high anthropic impact: the Atlantic Rainforest and the Pampa (Tabarelli et al. 2005, MMA 2008). The Atlantic Rainforest has lost approximately $95 \%$ of its coverage in Southern Brazil; only $0.37 \%$ of area is protected within 19 conservation units (SEMA 2010). The Pampa is restricted to Southern Brazil and occupies nearly $63 \%$ of this area (IBGE 2004). Approximately half of the natural area was converted into agricultural and livestock areas.
The protected area of this biome corresponds to $1.45 \%$ of Southern Brazil and is distributed along 14 conservation units (SEMA 2010).

This study aimed at the utilization of panbiogeographic tools to identify the distribution patterns of the aquatic insect genera in wetland systems of an extensive area of Neotropical region $\left(\sim 280000 \mathrm{~km}^{2}\right)$. The specific aims of this study were to: (1) recognize the common patterns (generalized tracks) of distributions of the aquatic insects in Southern Brazil wetlands; (2) recognize the centers of origin of aquatic insects (biogeographic nodes) in Southern Brazil; (3) compare the distribution of the biogeographic units identified by the aquatic insects with the conservation units of Southern Brazil and (4) propose the prioritization of areas for aquatic insects conservation in the Neotropical region.

This survey was developed in a large number of wetland systems, ranging a wide gradient of altitude and latitude. Aquatic insects are an important trophic level in wetland systems, since they provide food for several wildlife species, such as fish and waterfowl. Furthermore, the insects are especially important for researchers who attempt to answer biogeographic questions and to understand global distributional patterns (Morrone 2006). In Southern Brazil wetlands, $70 \%$ of the macroinvertebrate composition was represented by aquatic insects (Stenert et al. 2004).

\section{MATERIALS AND METHODS}

Study area: The state of Rio Grande do Sul (RS) is located in Southern Brazil $\left(27^{\circ} 04^{\prime}\right.$

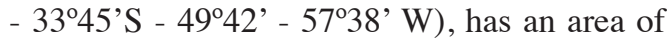
$282184 \mathrm{~km}^{2}$ and presents Humid Subtropical Mid-Latitude Climate. The annual precipitation varies between 1200 and $1800 \mathrm{~mm}$, and it is relatively well distributed along the year without the existence of a dry period (Cfclimate classification of Köpen). The mean temperature varies between $15^{\circ} \mathrm{C}$ and $18^{\circ} \mathrm{C}$, with minimum temperature bellow $10^{\circ} \mathrm{C}$ in the winter and maximum temperature above $32^{\circ} \mathrm{C}$ in the summer (RADAMBRASIL 1986). 
The state of Rio Grande do Sul has approximately 3441 wetlands, presenting a total flood area of approximately $30332 \mathrm{~km}^{2}$ (Maltchik 2003). For this study, a total of 146 wetlands (Fig. 1) were selected in Southern Brazil based on three criteria: (1) area smaller than 10ha to ensure a representative measure of the total richness and composition of each wetland, (2) presence of macrophytes, since the aquatic vegetation is a wetland indicator (Tiner 1999) and (3) fairly even distribution of the wetlands across Southern Brazil to cover an extensive area of the Neotropical region and a wide altitudinal and climatic gradient. Among all wetlands, 99 were sampled at Pampa (with maximum altitude of $270 \mathrm{~m}$ ) and 47 were sampled at the Atlantic Rainforest (altitudes between 90 and $990 \mathrm{~m}$ ). Each wetland was sampled once from March-October 2002, always during the period with surface water. The wetland area was measured in the field, and the wetland location and altitude were determined using a GPS receiver (model GPS III Plus, Garmin).

Aquatic insect sampling: Aquatic insect collections were carried using a kick net (D-shaped, $30 \mathrm{~cm}$ in width, $400 \mu \mathrm{m}$-opening mesh). Sampling was limited to the littoral zone of wetlands (water depths of less than $50 \mathrm{~cm}$ ), kicking up the substrate and then sweeping above the disturbed area to capture dislodged or escaping aquatic insects (Rosenberg et al. 1997). The sampling effort was the same for all wetlands, represented by 25 sweeps of $1 \mathrm{~m}$ over several habitats of the littoral zone (detritus, rooted macrophytes and other dominant vegetation). Sweeps were pooled into one sample per wetland (3.5-1 plastic bucket) and preserved in situ with $10 \%$ formaldehyde.

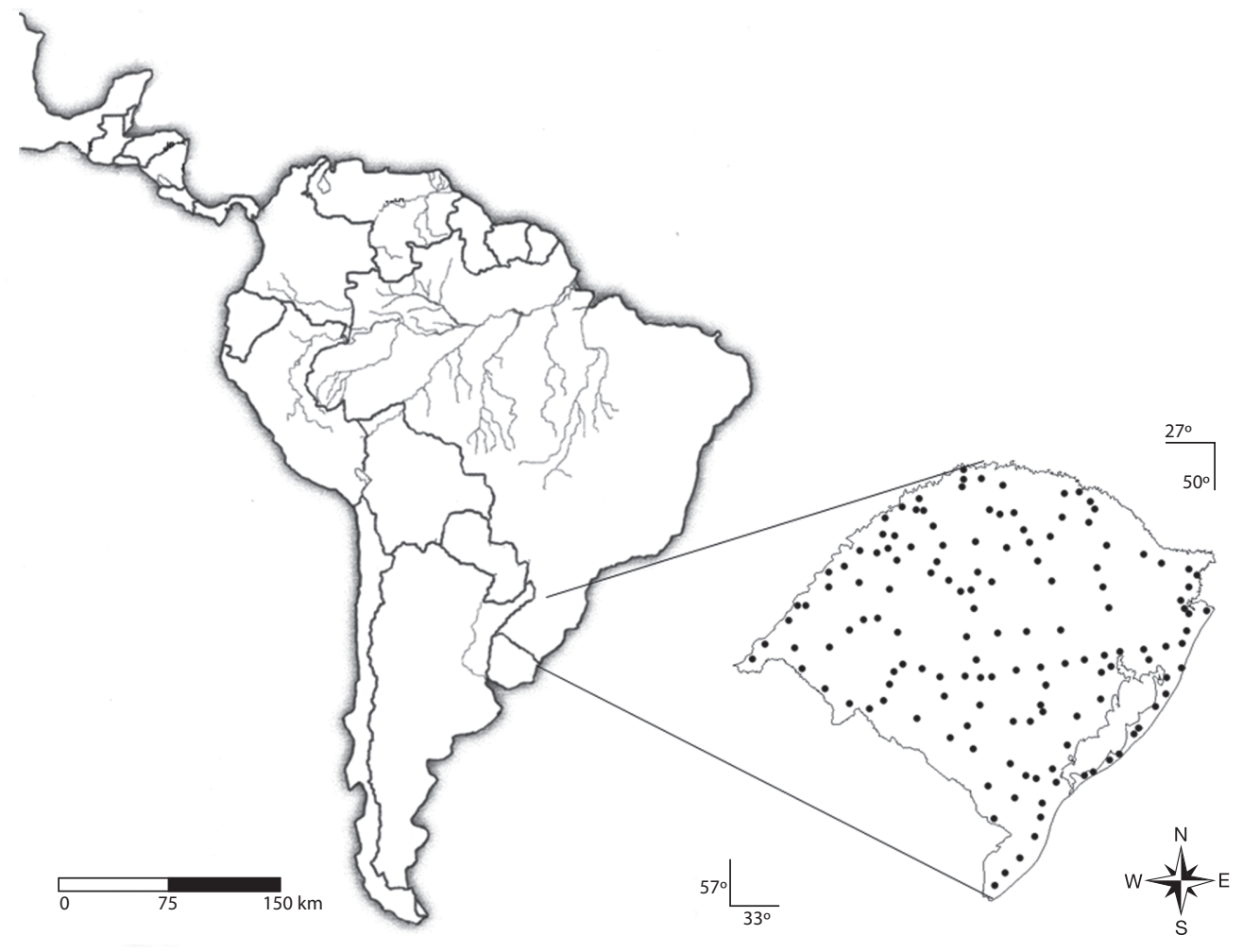

Fig. 1. Wetlands sampled in the state of Rio Grande do Sul, Southern Brazil. 
In laboratory, each sample was washed through a $400 \mu \mathrm{m}$ sieve, being the leaves, the stems, and other debris removed. The remaining material was preserved with $80 \%$ ethanol. Aquatic insects were separated and identified up to genus level under 7X magnification, according to Lopretto \& Tell (1995), TrivinhoStrixino \& Strixino (1995), Merritt \& Cummins (1996), Fernández \& Domínguez (2001) and the aid of specialists.

The data regarding the distribution of the genera of aquatic insects from four orders were considered for the analysis: Diptera (Chironomidae), Ephemeroptera, Odonata and Trichoptera. The criterion used for selecting the genera was the presence of more than one wetland in Southern Brazil.

The panbiogeographic approach basically consists of plotting distributions of different taxon on maps, connecting their separate localities with lines called individual tracks (Fig. 2A). When different individual tracks are superposed, the resulting summary lines are considered generalized tracks, which indicate the pre-existence of ancestral biotic components that were fragmented in the past due to tectonic and/or climatic changes. When two or more generalized tracks converge in a given area, they determine a node, which represents a complex area where different ancestral geological and biotic components interrelate in time and space (Morrone \& Crisci 1995).

The analysis of the generalized tracks and biogeographic nodes was carried individually for each order and for all orders together. First, individual tracks were built for each genus by plotting their localities of occurrence on maps and connecting them through the criterion of minimal distance. The generalized tracks were determined from the areas of superposition of the individual tracks, according to the methodology of Luna-Vega et al. (2000). Posteriorly, the biogeographic nodes were marked at the points of intersection or points of proximity of two or more generalized tracks. The identified biogeographic nodes were ranked through the quantification of the number of generalized tracks that supported them, therefore forming a set of ranked areas according to their importance as center of biodiversity. The resulting map was submitted to a cluster based on the distance, where the nodes close to $55 \mathrm{~km}$ were united to detect priority areas. The map was also superposed and compared with the map of conservation units in Southern Brazil. Individual and generalized tracks were drawn using the geoprocessing software GPS Track Maker®.

Since each wetland was sampled once from March-October (eight months), the influence of the sampling period (seasonal element) on the insect distribution patterns was analyzed to identify if tracks, and therefore nodes, reflect true biogeographic patterns rather than sampling seasonality. Partial mantel correlation tests (using the Pearson correlation method) were used to verify the effect of spatial structure (measured as geographic distance) and the effect of sampling period (measured as distance in months) on the faunal similarity. Three distance matrices were constructed: A) Faunal distance matrix based on genera presence and absence (dependent variable); B) Geographic distance matrix based on latitude and longitude coordinates (predictor variable) and C) Time distance between samples, based on months in which each wetland was sampled once (predictor variable). While the faunal matrix was constructed using Jaccard distance, the geographic and time matrices were constructed using Euclidean distance. The partial mantel test uses partial correlation (faunal $\mathrm{x}$ geographic distances) conditioned by the time distance. If the partial mantel test did not indicate a spatial structure on fauna composition, a simple mantel correlation test was used to verify the effect of sampling period on faunal similarity. Mantel correlation tests were analyzed for aquatic insects (Odonata +Ephemeroptera+Trichoptera+Chironomidae) and for each invertebrate group separately. The analyses were performed using R statistical program version 2.9.0 ( $\mathrm{R}$ Development Core Team 2009). Wetlands without taxon occurrence were removed from the analysis. The significance of correlations was tested by permutations (9 999 permutations). Moreover, 

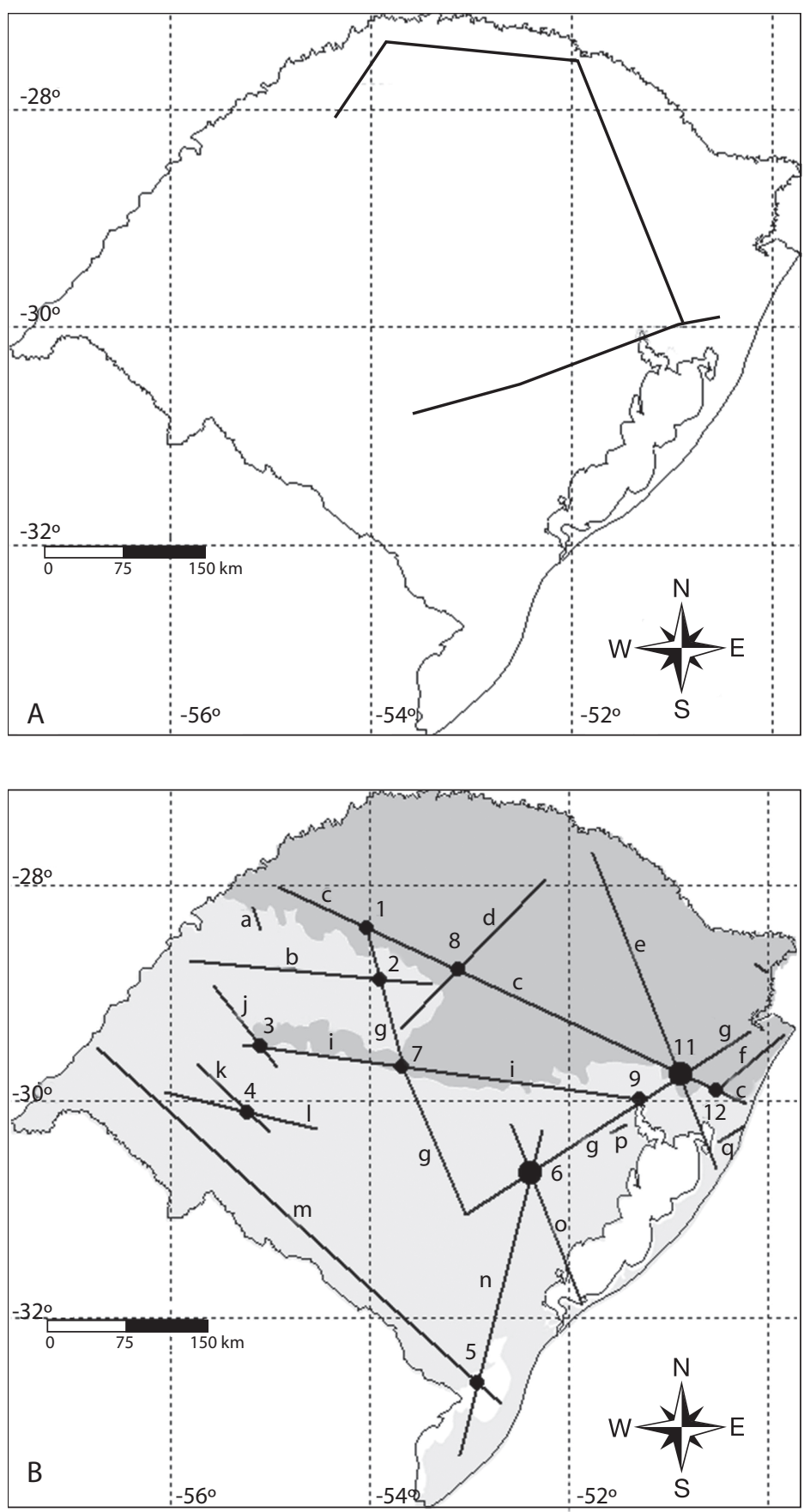

Fig. 2. (A) Example of individual track of Anax sp.; (B) Generalized tracks and nodes of Chironomidae. 
to verify if the biogeographic nodes simply represented the richest areas a simple linear regression was applied between the number of nodes and the number of insect genera collected on each area, which corresponded to square grids of $1 \mathrm{x} 1$ degree. In each square grid, the number of nodes and the total insect richness were analyzed, considering the sampled wetlands in each area.

\section{RESULTS}

Insect distribution: The data regarding the distribution in Southern Brazil wetlands revealed 82 genera -37 of Chironomidae (Diptera), 29 of Odonata, eight of Ephemeroptera and eight of Trichoptera from 13 families. Based on the 82 genera analyzed, 63 individual tracks were obtained with at least two wetlands recorded for each genus. The generalized tracks were created from 46 genera of aquatic insects (Table 1).

The genera of Chironomidae (Diptera) defined 17 generalized tracks and 11 biogeographic nodes in Southern Brazil wetlands (five nodes in the Pampa and five nodes in the Atlantic Rainforest) (Fig. 2B). The most important generalized tracks were $g$ and $o$, created from six and five individual tracks, respectively. The track $g$ is located in both biomes, whereas the track $o$ is located in the Pampa (Fig. 2B). The most important nodes were 6 and 11 -both supported by three generalized tracks. The node 6 -located in the Pampa- was defined by the tracks $g, n$, and $o$, and the node 11 -located in the Atlantic Rainforest- was represented by the tracks $c, e$ and $g$ (Table 2, Fig. 2B).

The genera Ephemeroptera defined three generalized tracks and three biogeographic nodes in Southern Brazil wetlands (Fig. 2C). The generalized track $c$ was defined by three individual tracks of the genera Americabaetis, Cloedes, and Caenis. The other two generalized tracks $-a$ and $b$ - were presented by two individual tracks each (Fig. 2C). The generalized tracks $a$ and $c$ are located in the Pampa; the track $b$ is located in the transition of both biomes. The biogeographic nodes were represented by two generalized tracks each, and they are located in the Pampa (Table 2, Fig. 2C).

The genera of Odonata identified 12 generalized tracks and nine biogeographic nodesseven nodes in the Atlantic Rainforest and two in the Pampa (Fig. 2D). The most important generalized tracks were $h$ (represented by seven individual tracks), and $f$ (represented by eight individual tracks) (Table 2). The track $h$ was defined by the genera Coryphaeschna, Acanthagrion, Cyanallagma, Homeoura, Oxyagrion, Micrathyria, and Tramea, and was mainly associated with the biome Atlantic Rainforest. The track $f$ was represented by Cyanallagma,

TABLE 1

Aquatic insect genera considered for the panbiogeography analysis

\begin{tabular}{ll}
\multicolumn{1}{c}{ Order } & \multicolumn{1}{c}{ Insect genera } \\
$\begin{array}{l}\text { Diptera } \\
\text { (Chironomidae) }\end{array}$ & $\begin{array}{l}\text { Ablabesmyia, Alotanypus, Apedilum, Beardius, Caladomyia, Chironomus, Clinotanypus, Coelotanypus, } \\
\text { Corynoneura, Cricotopus, Cryptochironomus, Dicrotendipes, Djalmabatista, Fissimentum, } \\
\text { Goeldichironomus, Harnischia complex, Labrundinia, Larsia, Lauterborniella, Macropelopia, } \\
\text { Monopelopia, Nanocladius, Parachironomus, Parametriocnemus, Paratendipes, Polypedilum, } \\
\text { Procladius, Rheotanytarsus, Tanypus, Tanytarsus, Thienemannimyia, Zavreliella, Zavrelimyia }\end{array}$ \\
Ephemeroptera & Americabaetis, Caenis, Callibaetis, Campsurus, Cloeodes, Massartella \\
Odonata & $\begin{array}{l}\text { Acanthagrion, Anatya, Anax, Castoraeschna, Coryphaeschna, Cyanallagma, Dasythemis, Erythemis, } \\
\text { Gynacantha, Gynothemis, Homeoura, Leptobasis, Lestes, Micrathyria, Orthemis, Oxyagrion, }\end{array}$ \\
& Phyllocycla, Remartinia, Rhioaeschna, Telebasis, Tramea \\
Trichoptera & Oecetis, Oxyethira, Phylloicus
\end{tabular}



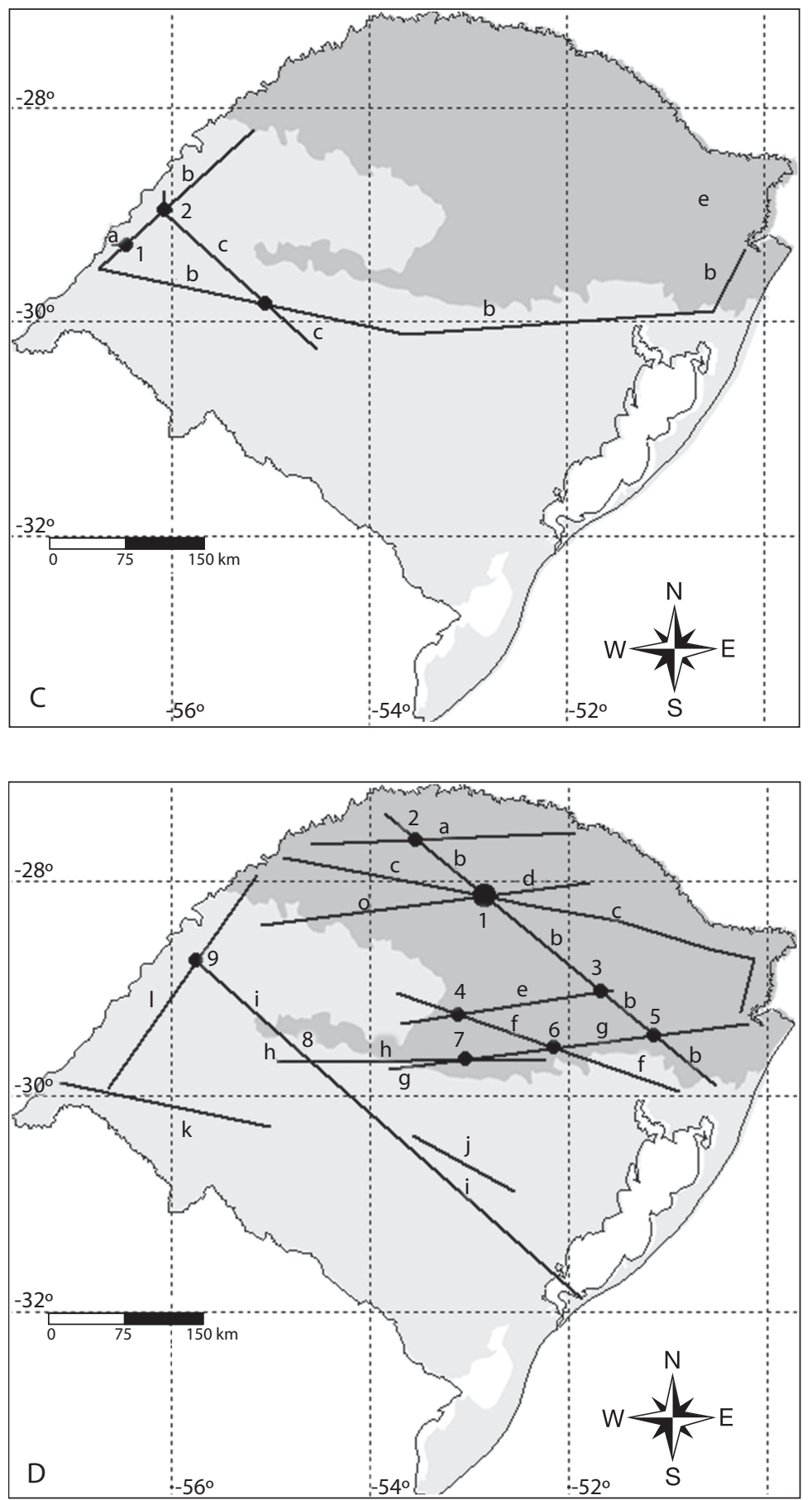

Fig. 2. (C) Generalized tracks and nodes of Ephemeroptera; (D) Generalized tracks and nodes of Odonata. 
TABLE 2

Generalized tracks and biogeographic nodes identified in Southern Brazil wetlands

\begin{tabular}{|c|c|}
\hline Order & Generalized tracks and nodes \\
\hline $\begin{array}{l}\text { Chironomidae } \\
\text { (Diptera) }\end{array}$ & 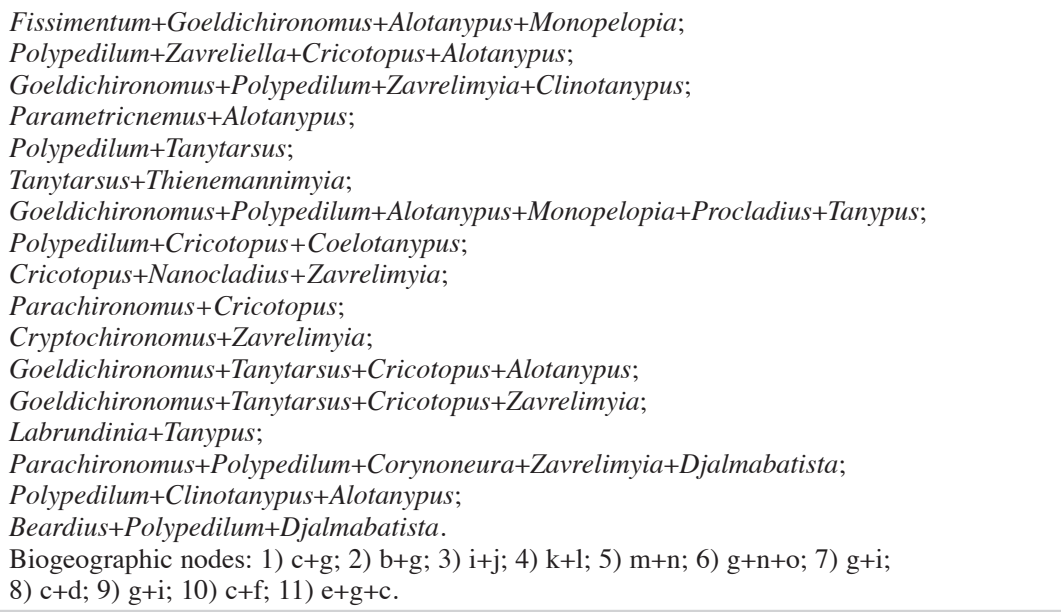 \\
\hline Ephemeroptera & $\begin{array}{l}\text { Cloedes+Caenis; } \\
\text { Callibaetis+Caenis; } \\
\text { Americabaetis+Cloedes+Caenis. } \\
\text { Biogeographic nodes: 1) a+b; 2) b+c; 3) b+c. }\end{array}$ \\
\hline Odonata & 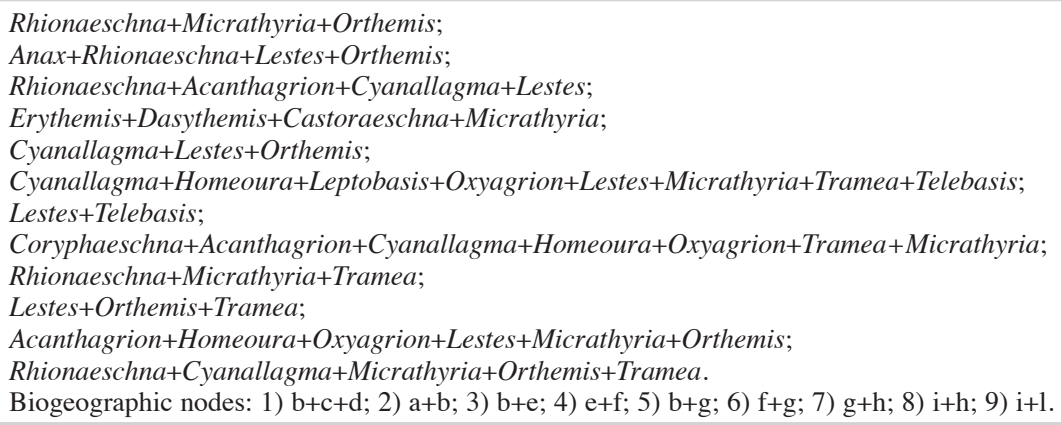 \\
\hline Order & Generalized tracks and nodes \\
\hline Trichoptera & Oecetis+Oxyethira \\
\hline Total & 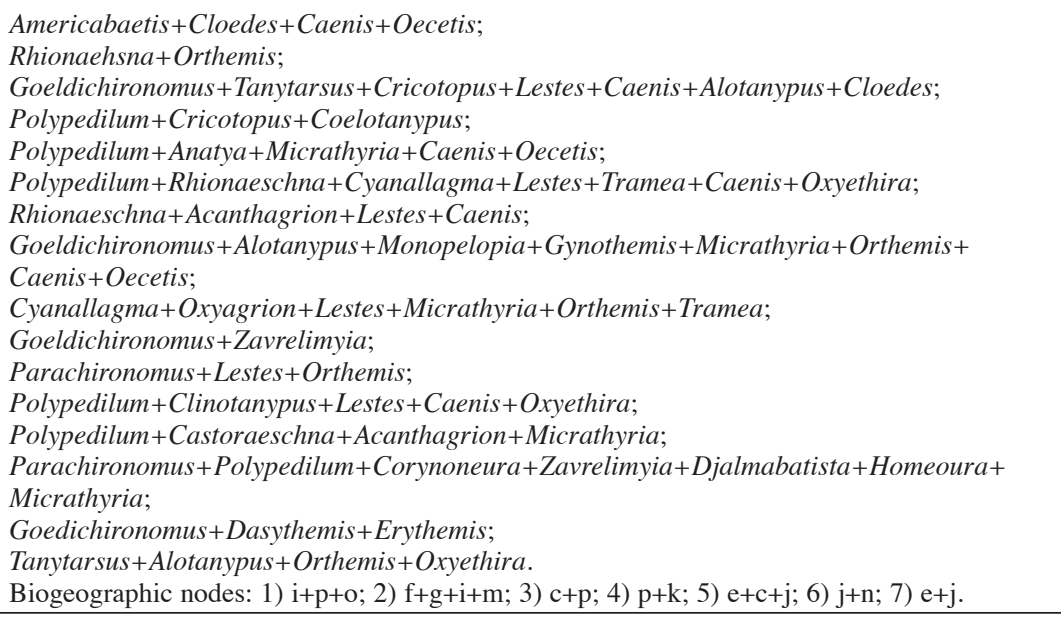 \\
\hline
\end{tabular}



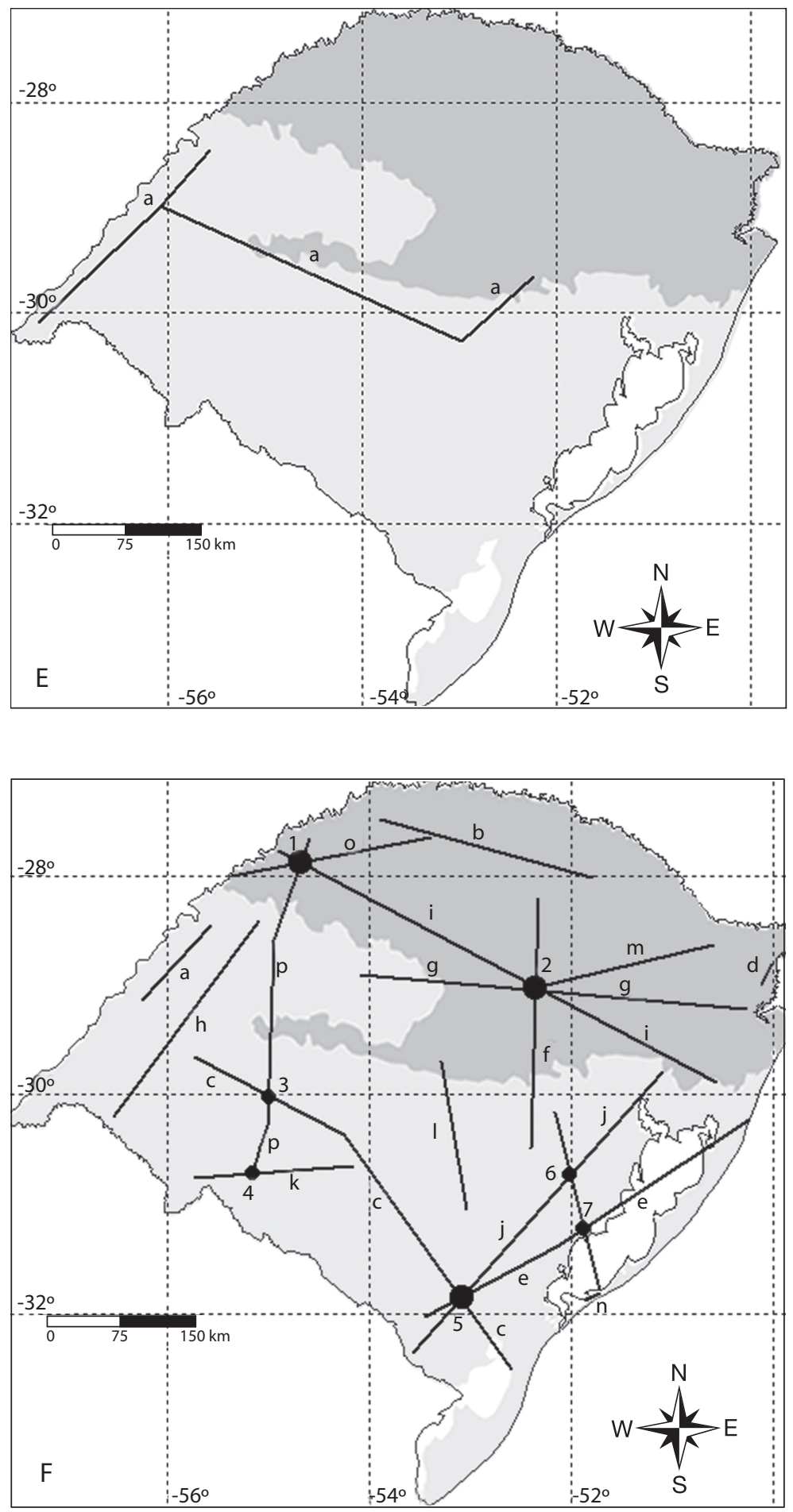

Fig. 2. (E) Generalized tracks and nodes of Trichoptera and (F) Generalized tracks and nodes of all groups (For detail see Table 2). 
Homeoura, Leptobasis, Oxyagrion, Lestes, Micrathyria, Tramea, and Telebasis, and was located in both biomes. The most important biogeographic node was $l$ located in the Atlantic Rainforest (Table 2, Fig. 2D). The genera of Trichoptera defined only one generalized track, but no biogeographic node (Table 2, Fig. 2E). The track identified by the genera Oecetis and Oxyethira link both biomes.

The superposition of all 63 individual tracks defined 16 generalized tracks and seven biogeographic nodes represented by different orders of aquatic insects (Table 2, Fig. 2F). The generalized track $h$ was defined by eight genera of Chironomidae, Odonata, Ephemeroptera, and Trichoptera. Other important generalized tracks were $c, f$, and $n$-all represented by seven individual tracks each (Fig. 2F). The most important biogeographic nodes defined by three generalized tracks, at least, were: one, represented by the generalized tracks $i, p$, and $o$ and all located in the Atlantic Rainforest; $t w o$, represented by the generalized tracks $\mathrm{f}, g, i$, and $m$ and all located in the Atlantic Rainforest; and five, represented by the generalized tracks $c, e$, and $j$ and all located in the Pampa (Table 3, Fig. $2 \mathrm{~F})$. The other four biogeographic nodes were located in the Pampa (Fig. 2F).

Implications for conservation: All generalized tracks and biogeographic nodes identified in Southern Brazil wetlands were superposed in a summary map (Fig. 3A). Therefore, 32 biogeographic nodes corresponded to the priority areas for conservation of the aquatic insect diversity in Southern Brazil wetlands. Among this total, 13 were located in the Atlantic Rainforest, 16 in the Pampa, and three amongst both biomes (Fig. 3A). According to the node cluster criterion, the priority regions for conservation were the following: (a) Site one $\left(\sim 9000 \mathrm{~km}^{2}\right)$, located in the Western region in the Pampas, presenting two main areas that totalize ten nodes; (b) Site two $\left(\sim 1000 \mathrm{~km}^{2}\right)$, located in the South-eastern region, in the Pampa and represented by the three nodes; (c) Site three $\left(\sim 7000 \mathrm{~km}^{2}\right)$, located in the Eastern region, in the Atlantic Rainforest, and represented by four nodes; and (d) Site four $\left(\sim 6000 \mathrm{~km}^{2}\right)$, located in the central region, in the Atlantic Rainforest and presented by three nodes (Fig. 3B).

The comparison between the distribution of the biogeographic nodes and the distribution of the conservation units in Southern Brazil, showed that several priority areas for the conservation of the diversity in aquatic insects are found outside the conservation units (Fig. 4). Only five out of 32 biogeographic nodes (approximately 15\%) were partially within the conservation units (three nodes in the Pampa, one node in the Atlantic Rainforest, and one node between both biomes). The corresponding areas to the other biogeographic nodes were not inserted in the conservation units (Fig. 4).

All genera composition matrix was correlated with geographic distance matrix $(\mathrm{r}=0.118, \mathrm{p}=0.001)$. When we analyzed each invertebrate group separately, Trichoptera and Chironomidae genera were correlated with geographic distance matrix $(\mathrm{r}=0.094, \mathrm{p}=0.016$ and $\mathrm{r}=0.072, \mathrm{p}=0.001$, respectively). Odonata and Ephemeroptera genera were not correlated with geographic distance matrix $(\mathrm{r}=0.037$,

TABLE 3

Summary of panbiogeography analysis results, for the aquatic insect genera in Southern Brazil wetlands: GT- Generalized tracks; BN - Biogeographic nodes

\begin{tabular}{lcccc}
\multicolumn{1}{c}{ Order } & GT & Most important GT & BN & Most important BN \\
Diptera (Chironomidae) & 17 & "o" & 11 & "6" and "11" (3 tracks) \\
Ephemeroptera & 3 & "c" & 3 & All represented by 2 tracks \\
Odonata & 12 & "h" and "f" & 9 & "1" (3 tracks) \\
Trichoptera & 1 & "a" & 0 & 0 \\
All orders & 16 & "h" "f", "g", "i", "m" & 7 & "2" (4 tracks) "1" and "5" (3 tracks) \\
\hline
\end{tabular}




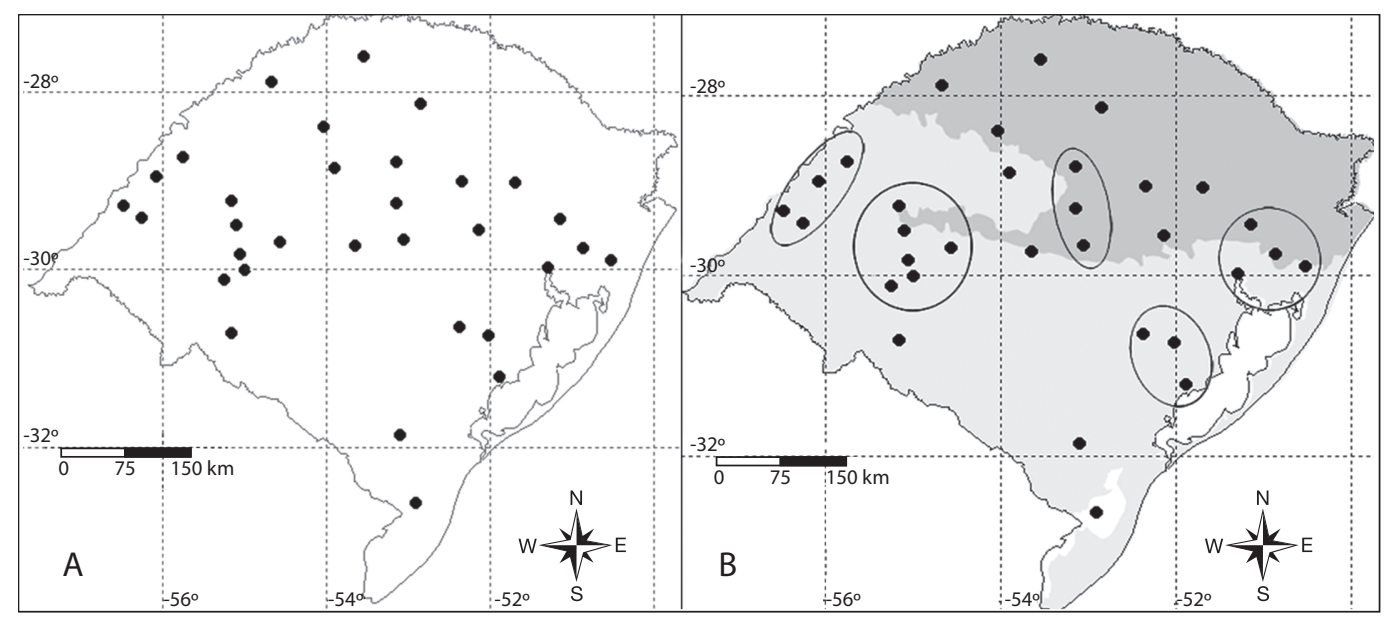

Fig. 3. (A) Biogeographic nodes identified in Southern Brazil wetlands and (B) Priority areas for the conservation of the aquatic insect diversity pointed by node cluster criterion in Southern Brazil wetlands.

$\mathrm{p}=0.138$ and $\mathrm{r}=0.057, \mathrm{p}=0.085$, respectively), nor with sampling seasonality matrix $(\mathrm{r}=0.025$, $\mathrm{p}=0.201$ and $\mathrm{r}=0.015, \mathrm{p}=0.34$, respectively). These results showed that the distribution patterns of aquatic insects genera in Southern
Brazil wetlands were not influenced by the sampling period.

On the other hand, the number of nodes was loosely correlated with the number of genera collected in the studied wetlands $\left(\mathrm{R}^{2}=0.267\right.$,

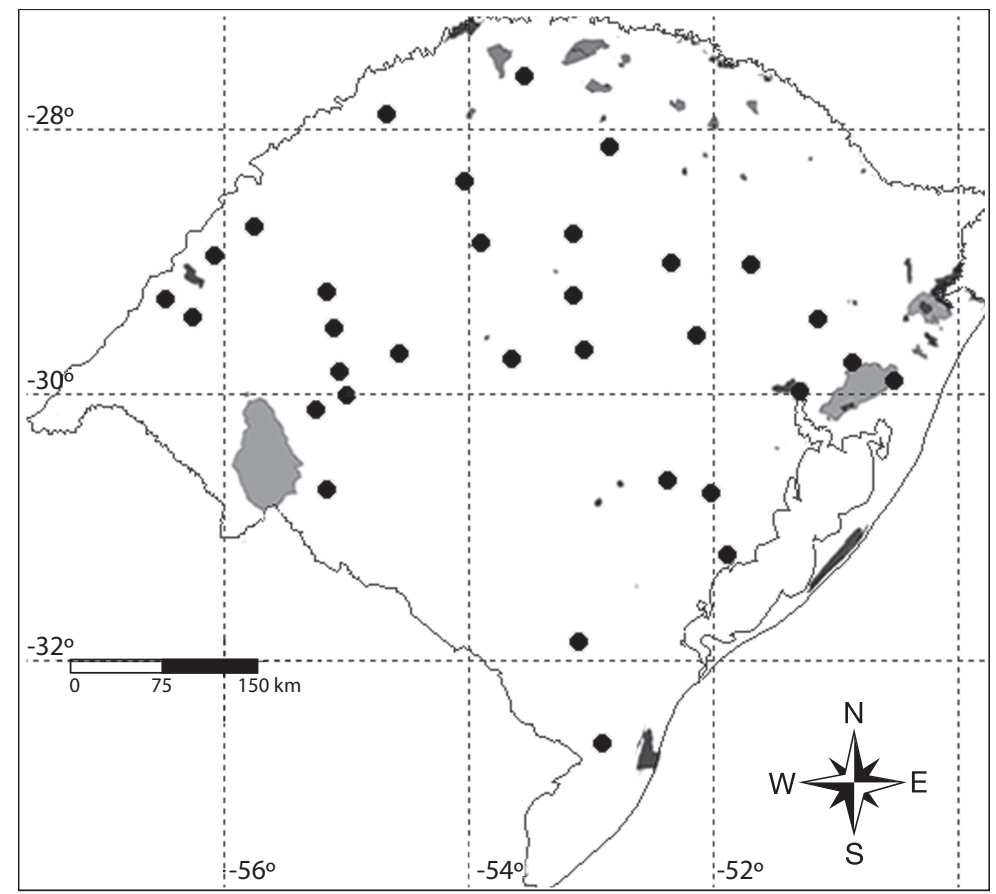

Fig. 4. Comparison between the distribution of the biogeographic nodes (black filled circles) and the distribution of the conservation units (shaded grey regions) in Southern Brazil. 
$\left.\mathrm{F}_{1,40}=13.862, \mathrm{p}<0.001\right)$. In this sense, the number of nodes cannot be highly predicted by insect richness because the major portion of variation in the number of nodes was not explained by insect richness, given that many areas fall far from the regression line (coefficient of determination of only 0.267) (Fig. 5).

\section{DISCUSSION}

Insect distribution: Congruences of biogeographic patterns of the phylogenetically related groups may be more associated to a common natural history than to independent dispersion events. Independent dispersion events occur as a reaction from each group to different environmental conditions (Gullan \& Cranston 2008). The coinciding patterns of individual tracks of genera analyzed (e.g. generalized track) indicated a narrow relationship between biota and studied region history. In this sense, we can infer that the current distribution patterns of the aquatic insects in Southern Brazil wetlands are determined mainly by vicariant events, and not by uncorrelated individual dispersions. However, we do not exclude the possibility that individual dispersal events have occurred, but after vicariant events.

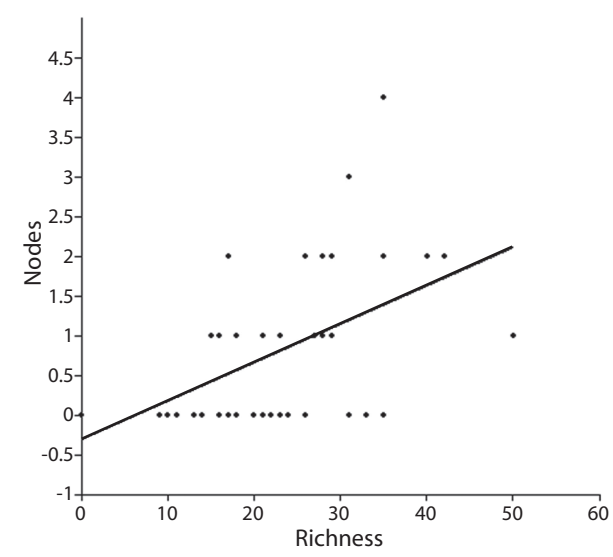

Fig. 5. Relationship between richness (number of insect genera) and number of nodes identified on each area (square grids, $\mathrm{n}=40$ ). In each area, the number of nodes and the total insect richness were analyzed, considering the sampled wetlands.
The faunal similarity observed was not influenced by the sampling period, but by the natural history of aquatic insects. Since the studied groups present ephemeral adults and immature stages associated to aquatic habitats, dispersions of long distance are less likely to explain the observed convergences. Odonata, Ephemeroptera, Chironomidae, Plecoptera, Trichoptera present overlapped distributions in the Southern Hemisphere even in low taxonomic levels (genus, species) (Gullan \& Cranston 2008). The current geographic distribution of aquatic insects suggests that their direct ancestors already inhabited the Gondwana supercontinent and were subject to vicariant events, such as the formation of continents (Gullan \& Cranston 2008). In this sense, the tracks and, therefore, the observed nodes reflected the biogeographic patterns related to the spatial structure of the biota rather than to sampling seasonality.

The distribution patterns found varied between the studied biomes. Most of the tracks and nodes found for different orders of aquatic insects were within the Pampa, excepting for Odonata. For Chironomidae, ten out of 17 generalized tracks were located in the Pampa. According Ferrington (2008), intermittent and ephemeral aquatic ecosystems, like Brazilian lowlands, are habitats where chironomids have wide geographic distribution and this relation is closely related to the patterns of transantartic diversification and vicariance (Brundin 1966). The same distribution pattern was observed for Ephemeroptera, which concentrated almost its tracks in the Pampa. According to BarberJames et al. (2008), mayflies are considered historically as insects of very low-dispersal ability in oceans and mountains -dispersal barriers. Therefore, the present distribution was explained only by vicariance, radiation, and extinction events and it was a reflection of geological events (Edmunds 1972, 1975). The region delimitated by the tracks of Ephemeroptera presented the lowest altitudes registered in Southern Brazil-what explains the coinciding pattern of distribution of its genera. 
Most of tracks of the Odonata genera were distributed in higher altitude of the Atlantic Rainforest. According to Kalkman et al. (2008), significant regions of the Odonata diversification include the regions with higher altitude, such as the Mexican Plateau, Chiapas to Honduras highlands, Costa Rica-Panama highlands, Northern and Southern Andes, Eastern Andean foothills, Tepuis of the Guyana Shield, Guyana lowlands, Atlantic Forests of Brazil and River Paraná basin. The occurrence of few tracks of Odonata in the Pampa was due to the wide distribution of two relatively recent Odonata families (Coenagrionidae and Libellulidae) (Rehn 2003). Almost all ubiquitous Odonata species observed belong to these two families, occurring in lentic water habitats of savannas, such as the wetlands in the Pampa.

The occurrence of two families of Trichoptera (Leptoceridae and Hydroptilidae) was expected in Southern Brazil. According to Eskov et al. (2004), these families were found in the extratropical, warm temperate latitudes of Laurasia (England and Siberia), and they dispersed in the Early Cretaceous across other landmasses including Gondwana (Brazil). A limited dispersal ability of both families of Trichoptera reflects the current distribution restriction of the genera found in Southern Brazil wetlands, since such order of aquatic insects was presented by a unique generalized track and by no biogeographic node at the region studied.

Despite the peculiarities in the distribution of each group, the general patterns of distribution of aquatic insects in Southern Brazil wetlands are related to the formation of the Atlantic Rainforest and the Pampa. The three most important biogeographic nodes supported by many generalized tracks, reflect a huge vicariant event at the studied region and represent large areas of aquatic biodiversity. The two largest nodes present in the Atlantic Rainforest are represented, mainly, by groups of wide distribution and greater diversification in higher altitude environments. Thus, the great biogeographic node present in the Pampa was represented by groups of aquatic insects distributed in areas located at lower altitudes and with restricted dispersal ability such as Ephemeroptera and Trichoptera. Such relation shows the importance of the landscape on the diversity and distribution of aquatic insects at the Neotropical region.

Implications for conservation: The biogeographic nodes guide historically the generalized regional tracks (Craw et al. 1999), since the patterns of distribution of the biota are influenced by the events that occur in each region. Such centers reflect indirectly the long-term maintenance of the biodiversity and spatial structure of the biota. They also include areas of high biogeographic diversity, since they are formed by samples of taxon and patterns of different origins, qualifying them as priority areas for conservation (Morrone 1999, Prevedello \& Carvalho 2006). Most of conservational actions taken today ignore the contributions offered by the historical and evolutionary studies. Some authors argue that more concrete decisions would be madden if information regarding the evolution of the areas and species could be incorporated into the conservation policies (Lowënberg-Neto \& Carvalho 2004). In our study, areas with a higher number of nodes were not necessarily the richest localities since residuals of the regression analysis indicated that panbiogeographic analysis can provide additional information on simple insect richness, and can be still considered as useful in conservation biogeography.

Our results showed that the conservation unit system in Southern Brazil do not contemplate several priority areas for the historical and biogeographic conservation of wetland aquatic insects. Several areas important for the conservation of the aquatic insects are unprotected and under strong anthropic pressure. The current occupation of these priority areas for conservation is related to silvicuture expansion and urbanization (sites two and three, respectively), and livestock and agriculture (sites one and four). Only 18 wetlands are under protection in conservation units in Southern Brazil (Carvalho \& Ozório 2007). The priority areas pointed by node cluster criterion must be 
considered in further inclusions of areas for biodiversity conservation in Southern Brazil wetlands, since such areas presents species from different ancestral biota. The inclusion of such areas into the conservation units would be a strong way to conserve the aquatic biodiversity in this region. Furthermore, our results show that the panbiogeography is an important tool to identify priority areas for the conservation of the aquatic biodiversity in Neotropical region (Morrone \& Espinosa 1998).

\section{ACKNOWLEDGMENTS}

This research was supported by funds from Universidade do Vale do Rio dos Sinos -UNISINOS (02.00.023/00-0), and Conselho Nacional de Desenvolvimento Científico e Tecnológico -CNPq (52370695.2). Leonardo Maltchik holds a Brazilian Research Council -CNPq Research Productivity grant. We declare that the data collection complied with the Brazilian current laws.

\section{RESUMEN}

La selección de áreas prioritarias es un enorme desafío para la conservación de la biodiversidad. Métodos biogeográficos se han utilizado para identificar áreas prioritarias para la conservación, como la panbiogeografía. Este estudio tuvo como objetivo el empleo de herramientas panbiogeográficas, para identificar los patrones de distribución de los géneros de insectos acuáticos, en los sistemas de humedales de una extensa área de la región Neotropical $\left(\sim 280000 \mathrm{~km}^{2}\right)$, y así comparar la distribución de las unidades biogeográficas identificadas por los insectos acuáticos, con las unidades de conservación del sur de Brasil. Asimismo, se analizaron los patrones de distribución de los 82 géneros de cuatro órdenes de insectos acuáticos (Diptera, Odonata, Ephemeroptera y Trichoptera) en los humedales del sur de Brasil. Ahora bien, 32 nodos biogeográficos correspondieron a las áreas prioritarias para la conservación de la diversidad de insectos acuáticos. Dentro de este total, 13 se encontraban en el Bosque Atlántico, 16 en la Pampa y tres entre los dos biomas. La distribución de nodos mostró que sólo el 15\% de los centros de dispersión de los insectos fueron insertados en las unidades de conservación. Las cuatro áreas prioritarias señaladas por criterio de nodo de clúster debe ser considerado en las inclusiones de los diferentes ámbitos para la conservación de la biodiversidad en los humedales del sur de Brasil, debido a que en esas zonas se presentan las 13 especies de la biota ancestrales diferentes. La inclusión de dichas áreas en las unidades de conservación sería una estrategia eficaz para conservar la biodiversidad acuática en la región.

Palabras clave: Panbiogeografía, análisis de trazos, áreas prioritarias, bioma, invertebrados acuáticos.

\section{REFERENCES}

Babbitt, K.J. 2005. The relative importance of wetland size and hydroperiod for amphibians in Southern New Hampshire. Wetl. Ecol. Manag. 13: 269-279.

Barber-James, H.M., J. Gattolliat, M. Sartori \& M.D. Hubbard. 2008. Global diversity of mayflies (Ephemeroptera, Insecta) in freshwater. Hydrobiologia 595: 339-350.

Brundin, L. 1966. Transantarctic relationships and their significance, as evidenced by chironomid midges with a monograph of the subfamilies Podonominae and Aphroteniinae and the austral Heptagyiae. K. Svenska Vetenskapsakad. Handl. 11: 1-472.

Carvalho, A.B.P. \& C.P. Ozório. 2007. Avaliação sobre os banhados do Rio Grande do Sul, Brasil. Rev. Cienc. Amb. 1: 83-95.

Carvalho, C.J.B., M. Bortolanza, M.C.C. Silva \& E.D.G. Soares. 2003. Distributional patterns of the Neotropical Muscidae (Diptera), p. 263-274. In J.J. Morrone \& J. Llorente (eds.). Una perspectiva latinoamericana de la biogeografía. Las Prensas de Ciencia, Facultad de Ciencias, UNAM, Ciudad de México, México.

Collinson, N.H., J. Biggs, A. Corfield, M.J. Hodson, D. Walker, M. Whitfield \& P.J. Williams. 1995. Temporary and permanent ponds: an assessment of the effects of drying out on the conservation value of aquatic macroinvertebrate communities. Biol. Conserv. 74: 125-133.

Contreras-Medina, R., I. Luna-Vega \& J.J. Morrone. 1999. Biogeographic analysis of the genera of Cycadales and Coniferales (Gymnospermae): a panbiogeographic approach. Biogeographica 75: 163-176.

Contreras-Medina, R. \& H. Eliosa-León. 2001. Una vision panbiogeográfico preliminary de México, p. 197-211. In J. Llorente \& J.J. Morrone (eds.). Introducción a la biogeografía en latinoamérica: teorías, conceptos, métodos y aplicaciones. Las Prensas de Ciencias, Facultad de Ciencias, UNAM, Ciudad de México, México.

Contreras-Medina, R., I. Luna-Vega \& O. Alcantara. 2001a. Las gimnospermas de los bosques mesófilos demontaña de la Huasteca Hidalguense, México. Bol. Soc. Bot. Mex. 68: 69-81. 
Contreras-Medina, R., J.J. Morrone \& I. Luna-Vega. 2001b. Biogeographic methods identify gymnosperm biodiversity hotspots. Naturwissenschaften 88: 427-430.

Craw, R.C., J.R. Grehan \& M.J. Heads. 1999. Panbiogeography; tracking the history of life. Oxford University, New York, USA.

Crisci, J.C., L. Katinas \& P. Posadas. 2003. Historical biogeography; an introduction. Harvard University, Cambridge, Massachusetts, USA.

Edmunds, G.F. 1972. Biogeography and evolution of Ephemeroptera. Ann. Rev. Entom. 17: 21-42.

Edmunds, G.F. 1975. Phylogenetic biogeography of mayflies. Ann. Mo. Bot. Gard. 62: 251-263.

Eskov, K.Y., V.D. Ivanov, I.D. Sukatsheva \& A. Wells. 2004. Geographic history of the family Hydroptilidae (Trichoptera). II Vserossiyskiy simpozium po amfibioticheskim i vodnym nasekomym, Voronezh, Russia.

Fernández, H.R. \& E. Domínguez. 2001. Guía para la determinación de los artrópodos bentónicos sudamericanos. Universidad Nacional de Tucumán, Tucumán, Argentina.

Ferrington, L.C. 2008. Global diversity of non-biting midges (Chironomidae; Insecta-Diptera) in freshwater. Hydrobiologia 595: 447-455.

Franco-Rosselli, P. \& C.C. Berg. 1997. Distributional patterns of Cecropia (Cecropiaceae): a panbiogeographic analysis. Caldasia 19: 285-296.

Franco-Rosselli, P. 2001. Estúdios panbiogeográficos em Colômbia, p. 221-224. In J. Llorente \& J.J. Morrone (eds.). Introducción a la biogeografía en latinoamérica: teorías, conceptos, métodos y aplicaciones. Las Prensas de Ciencias, Facultad de Ciencias, UNAM, Ciudad de México, México.

Gibbs, J.P. 2000. Wetland loss and biodiversity conservation. Conserv. Biol. 14: 314-317.

Gomes, A.D.S. \& A.M.D. Magalhães Jr. 2004. Arroz irrigado no Sul do Brasil (Irrigated rice in Southern Brazil). Embrapa, Pelotas, Rio Grande do Sul, Brasil

Guadagnin, D. \& L. Maltchik. 2007. Habitat and landscape factors associated with Neotropical waterbird occurrence and richness in wetland fragments. Biodivers. Conserv. 16: 1231-1244.

Gullan, P.J. \& P.S. Cranston. 2008. Os insetos: um resumo de entomologia. Roca, São Paulo, Brasil.
IBGE - Instituto Brasileiro de Geografia e Estatística. 2004. Nota técnica do mapa de biomas do Brasil. Brasília, Distrito Federal, Brasil. (Downloaded: December 15, 2010, www.ibge.gov.br/ home/ geociencias/ default_prod.shtm\#MAPAS).

Kalkman, V.J., V. Clausnitzer, K.D.B. Dijkstra, A.G. Orr, D.R. Paulson \& J. Van Tol. 2008. Global diversity of dragonflies (Odonata) in freshwater. Hydrobiologia 595: 351-363.

Lopretto, E.C. \& G. Tell. 1995. Ecosistemas de aguas continentales: metodologías para su estudio. Ediciones Sur, La Plata, Buenos Aires, Argentina.

Löwenberg-Neto, P. \& C.J.B. Carvalho. 2004. Análise parcimoniosa de endemicidade (PAE) na delimitação de áreas de endemismos: inferências para conservação da biodiversidade. Nat. Conserv. 2: 58-65.

Luna-Vega, I., A.O. Alcántara, J.J. Morrone \& D. Espinosa. 2000. Track analysis and conservation priorities in the cloud forests of Hidalgo (Mexico). Divers. Distrib. 6: 137-143.

Maltchik, L. 2003. Three new wetlands inventories in Brazil. Interciencia 28: 421-423.

Margules, C.R., R.L. Pressey \& P.H. Williams. 2002. Representing biodiversity: data and procedures for identifying priority areas for conservation. J. Biosciences 27: 309-326.

Menu-Marque, S., J.J. Morrone \& C.L. Mitrovich. 2000. Distributional patterns of the South American species of Boeckella (Copepoda: Centropagidae): a track analysis. J. Crustacean Biol. 20: 262-272.

Merritt, R.W. \& K.W. Cummins. 1996. An introduction to the aquatic insects of North America. Kendall/Hunt, Dubuque, Iowa, USA.

MMA - Ministério do Meio Ambiente. 2006. Third national report to the convention on biological diversity. Ministério do Meio Ambiente, Brasília, Distrito Federal, Brasil.

MMA - Ministério do Meio Ambiente. 2008. Áreas prioritárias para conservação, uso sustentável e repartição de benefícios da biodiversidade brasileira. Ministério do Meio Ambiente, Brasília, Distrito Federal, Brasil.

Mondragón, E.A. \& J.J. Morrone. 2004. Propuesta de áreas para la conservación de aves de México, empleando herramientas panbiogeográficas e índices de complementariedad. Interciencia 29: 112-120.

Morrone, J.J. \& E.C. Lopretto. 1994. Distributional patterns of freshwater Decapoda (Crustacea: Malocostraca) in 
Southern America: a panbiogeographic approach. J. Biogeogr. 21: 97-109.

Morrone, J.J. \& J.V. Crisci. 1995. Historical biogeography: introduction to methods. Ann. Rev. Ecol. Syst. 26: 373-401.

Morrone, J.J. \& D. Espinosa. 1998. La relevancia de los atlas biogeográficos para la conservación de la biodiversidad mexicana. Ciencia 49: 12-16.

Morrone, J.J. 1999. How can biogeography and cladistics interact for the selection of areas for biodiversity conservation? A view from Andean weevils (Coleoptera: Curculionidae). Biogeographica 75: 89-96.

Morrone, J.J. 2001. Biogeografia de América Latina y el Caribe. M \& T - Manuales \& Tesis SEA, Aragon, Zaragoza, Spain.

Morrone, J.J. 2003. Homología biogeográfica primaria de la familia Trichodactylidae (Crustacea: Decapoda), p. 241-245. In J.J. Morrone \& J. Llorente (eds.). Una perspectiva latinoamericana de la biogeografía. Las Prensas de Ciencia, Facultad de Ciencias, Universidad Nacional Autónoma de México (UNAM), Ciudad de México, México.

Morrone, J.J. 2004. Panbiogeografía, componentes bióticos y zonas de transición. Rev. Bras. Entomol. 48: $149-162$

Morrone, J.J., S.A. Mazzucconi \& A.O. Bachmann. 2004 Distributional patterns of Chacoan water bugs (Heteroptera: Belostomatidae, Corixidae, Micronectidae and Gerridae). Hydrobiologia 523: 159-173.

Morrone, J.J. 2006. Biogeographic areas and transition zones of Latin America and the caribbean islands, based on panbiogeographic and cladistic analyses of the entomofauna. Ann. Rev. Entomol. 51: 467-494.

Prevedello, J.A. \& C.J.B. Carvalho. 2006. Conservação do Cerrado brasileiro: o método pan-biogeográfico como ferramenta para a seleção de áreas prioritárias. J. Nat. Conserv. 4: 39-57.

R Development Core Team. 2009. R: A language and environment for statistical computing. R Foundation for Statistical Computing, Vienna, Austria. (Downloaded: December 08, 2010, www.r-project.org).

RADAMBRASIL. 1986. Levantamento de recursos naturais. Instituto Brasileiro de Geografia e Estatística - IBGE, Rio de Janeiro, Brasil.

Rehn, A.C. 2003. Phylogenetic analysis of higher-level relationships of Odonata. Syst. Entom. 28: 181-239.
Roig-Juñent, S., G.E. Flores \& C. Mattoni. 2003. Considerations biogeográficas de la Precordillera (Argentina), con base en artrópodos epígeos, p. 275-288. In J.J. Morrone \& J. Llorente (eds.). Una perspectiva latinoamericana de la biogeografía. Las Prensas de Ciencia, Facultad de Ciencias, Universidad Nacional Autónoma de México (UNAM), Ciudad de México, México.

Rolon, A.S., T. Lacerda, L. Maltchik \& D.L. Guadagnin. 2008. The influence of area, habitat and water chemistry on richness and composition of macrophyte assemblages in Southern Brazil wetlands. J. Veg. Sci. 19: $221-228$.

Rosenberg, D.M., I.J. Davies, D.G. Cobb \& A.P. Wiens. 1997. Ecological monitoring and assessment network (EMAN - Environment Canada) - Protocols for measuring biodiversity: Benthic macroinvertebrates in freshwaters. Department of Fisheries \& Oceans, Freshwater Institute, Winnipeg, Manitoba, Canada.

Sarkar, S. \& C. Margules. 2002. Operationalizing biodiversity for conservation planning. J. Biosciences 27 : 299-308.

SEMA - Secretaria Estadual do Meio Ambiente. 2010. Unidades de conservação. Porto Alegre, Rio Grande do Sul, Brazil. (Downloaded: December 08, 2010, www.sema.rs.gov.br/sema/html/ bio.htm).

Shine, C. \& C. Klemm. 1999. Wetlands, water and the law: using law to advance wetland conservation and wise use. IUCN, Gland, Switzerland.

Snodgrass, J.W., M.J. Komoroski, A.L. Bryan Jr. \& J. Burger. 2000. Relationship among isolated wetland size, hydroperiod, and amphibian species richness: implications for wetland regulations. Conserv. Biol. 14: 414-419.

Stenert, C., E.M. Santos \& L. Maltchik. 2004. Levantamento da diversidade de macroinvertebrados em áreas úmidas do Rio Grande do Sul (Brasil). Acta Biol. Leopold. 26: 225-240.

Stenert, C. \& L. Maltchik. 2007. Influence of area, altitude and hydroperiod on macroinvertebrate communities in Southern Brazil wetlands. Mar. Freshwater Res. 58: 993-1001.

Stenert, C., R.C. Bacca, C.C. Mostardeiro \& L. Maltchik. 2008. Environmental predictors of macroinvertebrates communities in coastal wetlands of Southern Brazil. Mar. Freshwater Res. 59: 540-548.

Tabarelli, M., L.P. Pinto, J.M.C. Silva, M.M. Hirota \& L.C. Bedê. 2005. Desafios e oportunidades para a 
conservação da biodiversidade na Mata Atlântica brasileira. Megadiversidade 1: 132-138.

Tiner, R.W. 1999. Wetland indicators. Lewis, New York, USA.

Trivinho-Strixino, S. \& G. Strixino. 1995. Larvas de Chironomidae (Diptera) do Estado de São Paulo. Guia de
Identificação e Diagnose dos Gêneros. Universidade Federal de São Carlos, São Carlos, São Paulo, Brasil.

Van Geest, G.J., H. Wolters, F.C.J.M. Roosen, H. Coops, R.M.M. Roijackers, A.D. Buijse \& M. Scheffer. 2005. Water-level fluctuations affect macrophyte richness in floodplain lakes. Hydrobiologia 539: 239-248. 
